\title{
Urethritis and antimicrobial resistance
}

\author{
Zoran GOLUŠIN ${ }^{1,2 *}$, Olivera LEVAKOV², Biljana JEREMIĆ ${ }^{2}$ \\ ${ }^{1}$ Faculty of Medicine, University of Novi Sad, \\ ${ }^{2}$ Clinic of Dermatovenereology Diseaeses, Clinical Center of Vojvodina, Novi Sad \\ *Correspondence: Dr. Zoran Golušin, E-mail: zgolusin@eunet.rs
}

UDC 616.62-022.7-08:615.015.7

VERSITA

\begin{abstract}
Urethritis is a clinical syndrome which is characterized by mucopurulent or purulent urethral discharge with or without dysuria, due to an increased number of polymorphonuclear leukocytes in the anterior urethra. Antimicrobial therapy and preventive measures are essential in the management of bacterial urethritis. However, these drugs may cause antimicrobial resistance, resulting in unsuccessful treatment and complications of urethritis. Resistance of Neisseria gonorrhoeae to antibiotics is well known for decades, and in recent years there are more cases of resistance of Chlamydia trachomatis and Mycoplasma genitalium to different antibiotics. There is a danger that in the future certain strains of $\mathrm{N}$. gonorrhoeae will be resistant to all available antimicrobial agents, unless new antibiotics to which resistance will not develop rapidly or an effective vaccine are developed.
\end{abstract}

\section{Key words}

Urethritis + etiology + classification + prevention and control + therapy; Drug Resistance, Microbial

U rethritis is a clinical syndrome which is characterized by mucopurulent or purulent (Figures 1 and 2) urethral discharge with or without dysuria, due to an increased number of polymorphonuclear leukocytes in the anterior urethra. There are two types of urethritis. The first type is not sexually transmitted and occurs due to urinary tract infections, phimosis, bacterial prostatitis, chemical or mechanical irritation. Urethritis which is directly related to sexually transmitted diseases may be classified as: gonococcal and nongonococcal. Regarding its course, urethritis can be acute or chronic.

Neisseria gonorrhoeae is the most common cause of urethritis in Africa and South East Asia, while Chlamydia trachomatis is predominant in other geographic areas, especially in Europe and North America $(1,2)$. Table 1 shows the etiologic agents of nongonococcal urethritis (3).

When considering the etiology of nongonococcal urethritis, one should take into account microorganisms of partner's oropharyngeal flora and vaginal secretions during unprotected intercourse. Recently discovered bacteria should also be considered, for example Atopobium vaginae, an anarerobic bacterium, discovered in 1999, often found in the vagina causing bacterial vaginosis (4).

Antimicrobial drugs and preventive measures are essential in the treatment of bacterial urethritis. However, these drugs may cause antimicrobial resistance, resulting in unsuccessful treatment and complications such as: epididymo-orchitis, prostatitis, SARA (Sexually acquired reactive arthritis), pelvic inflammatory disease, ectopic pregnancy, perihepatitis and sterility.

Resistance of Neisseria gonorrhoeae to antibiotics is well known for decades, and in recent years there is an increasing number of reports on resistance of Chlamydia trachomatis and Mycoplasma genitalium to different antibiotics. In cases of persistent dysuria, sometimes it is difficult to assess whether there is resistance, and there are diagnostic and therapeutic shortcomings when indentifying the source of infection, reinfection or compliance. 


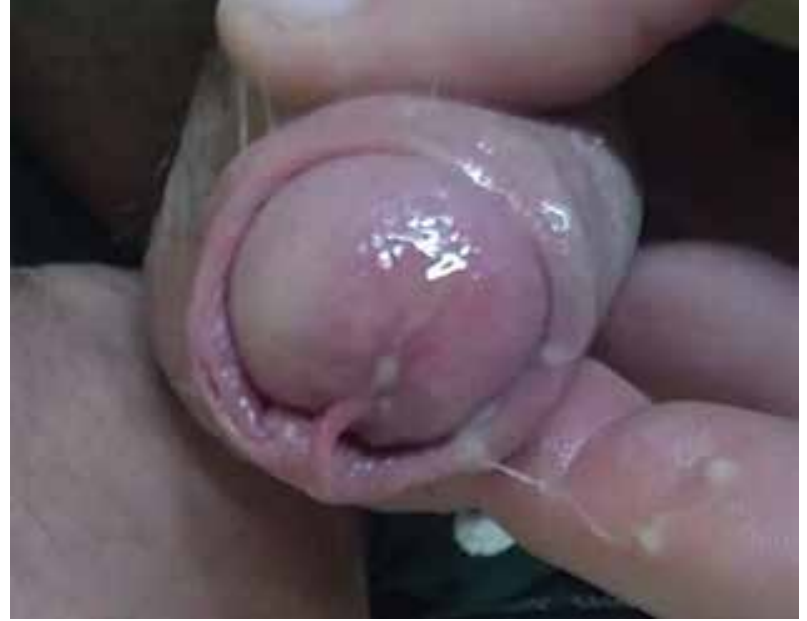

Figure 1a. Pus-like discharge from the penis: a diagnostic and therapeutic challenge

\section{Neisseria gonorrhoeae}

Treatment of gonorrhea has changed through history in many ways, from the old procedures (urethral adstringens, mechanical and chemical substances applied into the urethra), until the appearance of antibiotics. The first antibacterial drugs were sulfonamides, that appeared in 1936, while penicillin appeared seven years later $(5,6)$.
Penicillin was the standard treatment for gonorrhea, but decreased sensitivity to penicillin in the 1950 s to 1970 s required a change and a combination of penicillin and probenecid was recommended (7). In 1976, ß-lactamase encoding plasmids caused a high level of penicillin resistance, and in 1989, there was a significant level of resistance in U.S., and the drug was removed from the list of recommended therapy for gonorrhea $(8,9)$. A similar thing happened with tetracyclines which ceased to be the recommended treatment for gonorrhea in the U.S. and Western Europe in the late 1980s (10). Quinolones have been the first-line therapy since the mid 1980s to the early 90 in many countries. Except for urogenital, they were effective in the eradication of oropharyngeal and anorectal gonorrhea with a single oral dose of 500 $\mathrm{mg}$ of ciprofloxacin. Resistance was first observed in South East Asia, and later in other parts of the world, contributing to its exclusion as a first-line treatment of gonorrhea in the early and mid 2000s $(11,12)$.

Azithromycin, a relatively new macrolide, has shown significant efficacy in the treatment of gonorrhea. Cure rates of urethral and endocervical gonorrhea were $96.5 \%$ for $1 \mathrm{~g}$ azithromycin to $99 \%$ for $2 \mathrm{~g}$ azithromycin (13). However, some studies have

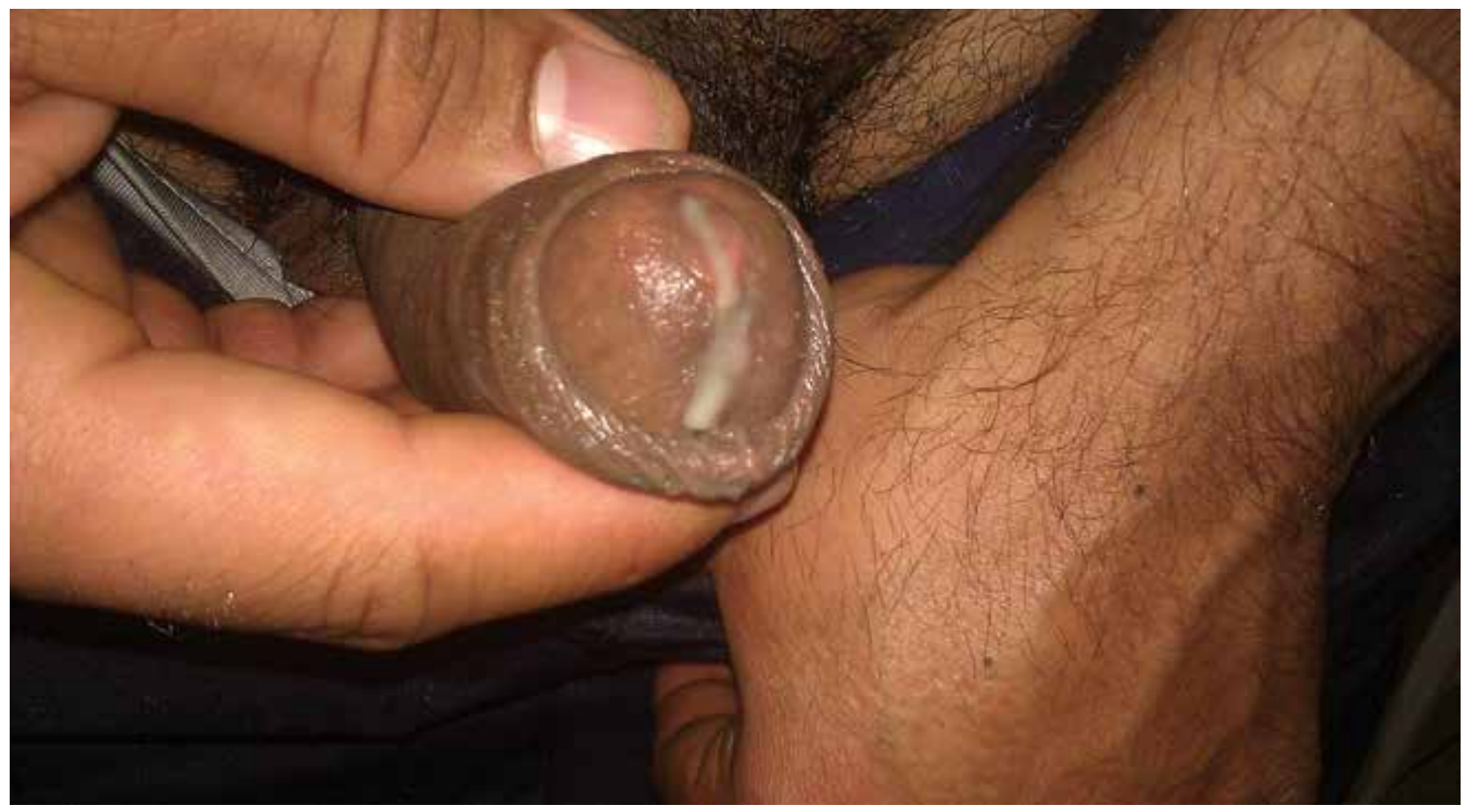

Figure 1b. Pus-like discharge from the penis 
Table 1. Causative agents of non-gonococcal urethritis

\begin{tabular}{lc} 
Causative agents & Frequency (\%) \\
Chlamydia trachomatis & $11-43 \%$ \\
\hline Mycoplasma and Ureaplasma & $9-25 \%$ \\
\hline Trichomonas vaginalis & $1-20 \%$ \\
\hline Adenoviruses & $2-4 \%$ \\
\hline Herpes Simplex virus type 1 and type 2 & $2-3 \%$ \\
\hline
\end{tabular}

shown a failure of treatment with $1 \mathrm{~g}$ of azithromycin, suggesting that the resistance can quickly develop if this dose is used (14). Due to rapid development of resistance, azithromycin has never been a firstline treatment in self-medication. It was used in combination with cephalosporins in the treatment of associated infections Neisseria gonorrhoeae and Chlamydia trachomatis infections.

Today, cephalosporins are the first line treatment of gonorrhea, showing high efficacy for urogenital, anorectal, and pharyngeal gonorrhea for years and decades. Cefriaxone has a long half-life of $6-9 \mathrm{~h}$ and is suitable for a single dose (10). Clinical trials, including pregnant women and children, have shown that cefriaxone at a dose of $250 \mathrm{mg}$ IM is suitable for the treatment of gonorrhea regardles of areas, with an efficiency of $99.2 \%$ for uncomplicated urogenital and anorectal cases of gonorrhea. Cefixime, an oral cephalosporin, showed similar efficacy as intramuscular ceftriaxone in the treatment of complicated gonorrhea. A single dose of $400 \mathrm{mg}$ of cefixime showed an efficacy of $95 \%$ of urogenital and anorectal gonorrhea $(13,15,16)$.

However, the high efficiency of cephalosporins is compromised by data from certain parts of the world about resistant strains of gonococci. The first data of gonorrhea treatment failure with third-generation cephalosporins were published in Japan in 2000 (17). Data on resistance to cephalosporins in other countries were published in the following years, and the first two cases of treatment failure with cefixime in Europe took place in Norway in 2010 (18). In Japan, high-level resistance to ceftriaxone of $N$. gonorrhoeae strain (strain H041) has recently been published (19). In Europe, the first case of genital infection with $N$. gonorrhoeae highly resistant to ceftriaxone was published in France in 2011 (20). The mechanisms of resistance to previously used agents are both plasmid and chromosome mediated (21). The question is how long cephalosporins will remain the first line treatment for gonorrhea. In the United Kingdom, the national guidelines have already been changed and recommend ceftriaxone as the first-line therapy with cefixime as an alternative (22). Due to the increase in the minimum inhibitory concentration of cefixime and ceftriaxone, there are recommendations to increase the dosage. However, the current dosage of $400 \mathrm{mg}$ cefixime is the highest single dose licensed for gonorrhea and so any increase would require multiple doses. The dilemma with ceftriaxone is that it is administered intramuscularly and this is not so palatable for adverse reactions. The recommendation of increasing the dose from 250 to $500 \mathrm{mg}$ and additionally adding 1 $\mathrm{g}$ azithromycin for all patients in order to delay any resistant mutants has been met with some skepticism and some believe that this is an over-reaction to a potential situation (23).

The recommended therapy for uncomplicated $N$. gonorrhoeae infections of the urethra, cervix and rectum in adults and adolescents, when the antimicrobial sensitivity of the infection is unknown, includes a single dose of $500 \mathrm{mg}$ ceftriaxone together with $2 \mathrm{~g}$ of azithromycin as a single oral dose. Alternative regimens are as follows: 1) a single dose of $400 \mathrm{mg}$ oral cefixime as together with a single oral dose of $2 \mathrm{~g}$ azithromycin; 2) a single dose of $500 \mathrm{mg}$ 
ceftriaxone IM; 3) a single dose of $2 \mathrm{~g}$ spectinomycin IM together with a single oral dose of $2 \mathrm{~g}$ azithromycin (24).

To reduce the risk of treatment failure (gonococcal treatment failure) there are recommendations to increase the dose of oral cefixime to $800 \mathrm{mg}$ for persons 9 years of age and older (25).

Because of this, there is a danger that in the future certain strains of $N$. gonorrhoeae will be resistant to all available antimicrobial agents, unless new antibiotics to which resistance will not develop rapidly, or an effective vaccine are developed.

New research suggests that treatment of gonococcal infections may include gentamicin, solithromycin and ertapenem.

In the African country of Malawi, a single dose of $240 \mathrm{mg}$ IM gentamicin was used as first-line treatment of gonorrhea. Limited surveys showed that apparently gonorrhea has not mutated and developed resistance to gentamicin in that country over the past two decades. Because of the necessary new research on the effectiveness of gentamicin, the American National Institutes of Allergy and Infectious Diseases (NIAID) is conducting a randomized clinical trial of the following interventions in cases of gonorrhea: 1) gentamicin $240 \mathrm{mg}$ (intramuscular injection) + azithromycin $2 \mathrm{~g}$ (orally); 2) gemifloxacin $320 \mathrm{mg}+$ azithromycin $2 \mathrm{~g}$, both drugs taken orally (26).

A new fluoroketolide, solithromycin, is a potential treatment option for gonorrhea. Solithromycin was tested in laboratory experiments, and strains of gonorrhea were resistant to at least one of the following antibiotics: azithromycin, ampicillin, cefixime, ceftriaxone, ciprofloxacin, spectinomycin, tetracycline and gentamicin. In all cases, solithromycin showed powerful antibacterial activity. Results from phase I and II studies suggest that solithromycin is well absorbed when taken orally and it accumulates inside cells. This drug has anti-inflammatory activity, which makes it useful for treating infections. At doses between 200 and $600 \mathrm{mg}$, it is well tolerated and safe $(27,28)$.

In vitro results suggest that ertapenem may be an effective treatment option against $N$. gonorrhoeae isolates particularly for the currently identified extended-spectrum cephalosporins resistant cases and possibly in a dual antimicrobial therapy regimen (29).
Ertapenem is a broad spectrum carbapenem antibiotic used primarily in the treatment of aerobic gramnegative bacterial infections.

\section{Mycoplasma}

Two mycoplasma species most commonly detected in the urethra are Mycoplasma hominis and Mycoplasma genitalium. The colonisation rate with Mycoplasma increases proportionally with the number of different sexual partners (30). There is no evidence supporting the role of $M$. hominis as a cause of urethritis. It is often isolated from the genital tract of healthy individuals (31).

M. genitalium has been strongly and uniformly associated with urethritis in more than 30 studies. It probably accounts for 15 to $20 \%$ of nongonococcal urethritis cases and it is the second most common cause of nongonococcal urethritis after $C$. trachomatis (32).

The main antibiotic classes used in the treatment of mycoplasmas are tetracyclines, macrolides, quinolones and clindamycin. M. hominis infections are treated with tetracyclines, quinolones and clindamycin, whereas M. hominis is intrinsically resistant to macrolides. M. genitalium is generally susceptible to tetracyclines, macrolides and quinolones in vitro, although tetracyclines are clinically ineffective (33).

Target alterations are the only acquired resistance mechanisms that have been described in vivo for $M$. genitalium. Mutations of the ribosome target, in the central loop of the $23 \mathrm{~S}$ rRNA domain V, are major $M$. genitalium resistance mechanisms to macrolides. In $85 \%$ of patients infected with mutant strains and unsuccessfully treated with $1 \mathrm{~g}$ azithromycin, there is a resistance to macrolides, which speaks in favor of azithromycin-induced resistance (34). Therefore, as previously noted for resistance to antibiotics, today there is no generally accepted standard treatment for M. genitalium.

Comparative therapeutic studies of infection with M. genitalium deal with the most commonly used medications: azithromycin and doxycycline. A Scandinavian study showed that the eradication rate of $M$. genitalium after 9 days of treatment with doxycycline $(200 \mathrm{mg}$ day one, then $100 \mathrm{mg}$ the following eight days) was $22 \%$, and with a single dose 
of $1 \mathrm{~g}$ of azithromycin it was $86 \%$ (35). In the study of Mena et al., azithromycin was also more efficient: a single dose of $1 \mathrm{~g}$ led to a cure rate of $87 \%$ of treated patients compared to $45 \%$ treated with doxycycline (200 mg for seven days). In an American study, azithromycin (1 $\mathrm{g}$ single dose) resulted in a cure in $66.7 \%$, and doxycycline $(200 \mathrm{mg} / \mathrm{d}$ for seven days) in $30.8 \%$ of treated patients (36). Azithromycin is superior to doxycycline, but the dose and duration of therapy remain to be considered. In studies where azithromycin was used for five days (day one $500 \mathrm{mg}$, $250 \mathrm{mg}$ from day 2 to day 5) eradication rates were $100 \%$ (37). Establishment of acquired resistance to macrolides prior therapy would reduce the number of unsuccessful treatment trials.

However, one study showed that azithromycin has a proarrhythmic effect. Although several macrolides are proarrhythmic and associated with an increased risk for sudden cardiac death, published reports of arrhythmias suggest that azithromycin may increase the risk of cardiovascular death (38).

From other antibiotics, moxifloxacin has proven effective (seven to ten days treatment) in patients who were unsuccessfully treated with macrolides and tetracyclines (39).

Despite acquired resistance to macrolides, the first-line treatment of urethritis caused by $M$. genitalium is $1 \mathrm{~g}$ single dose of azithromycin with PCR test of cure and microbiological eradication at least 3 weeks later. If this therapy fails, and M. genitalium persists, moxifloxacin $400 \mathrm{mg}$ a day for 7 to 10 days is recommended. Five-day azitromycin or moxifloxacin should be used as first-line treatment for upper genital tract M. genitalium infection and post-treatment bacterial eradication should always be checked to prevent long-term complications (40).

\section{Ureaplasma}

In contrast to the consistency of studies associating M. genitalium with urethritis, the role of ureaplasma in this disease has been more controversial. The results of studies support a causal role of ureaplasma in nongonococcal urethritis, particularly in its chronic form (41). Ureaplasma urealitycum has been reported as a causal agent of acute urethral syndrome in women with reproductive failure (42). This bacterium may also be an etiological factor for urethritis in men (43). Other species of human ureplasmas, like Ureaplasma parvum, were isolated more often in control groups, indicating that this species has a lower pathogenic potential. Some patients with hypogammaglobulinemia may develop a prolonged urethritis with persistent ureaplasmal infection (44).

Ureaplasmas are susceptible to tetracyclines, quinolones and macrolides, whereas clindamycin is mostly ineffective.

Reports of macrolide resistance in ureaplasmas go back to the 1980s. The first description of highlevel macrolide resistance in human ureaplasmas accompanied characterization of the mechanism involved. Macrolide influx and accumulation, as well as binding affinity to the ribosomes, were reduced in macrolide-resistant isolates (45). Mechanisms of resistance in $U$. parvum were characterized by sequencing portions of genes encoding $23 \mathrm{~S}$ rRNA and ribosomal protein L4 and L22. Mutants with significantly increased minimum inhibitory concentrations could be selected with many antibiotics, except different macrolides and related antibiotics. Most of the mutations were associated with complete loss of macrolide and ketolide activity, whereas streptogramin combinations were less affected (46). Resistance of ureaplasmas to erythromycin is still a matter of debate. Some authors found a great proportion of erythromycin-resistant strains, whilst others did not (47). Authors from China reported target site methylation and active efflux mechanisms in clinical isolates of macrolide-resistant ureaplasmas (48).

Treatment of urethritis caused by ureaplasma is performed according to recommendations for treatment of chronic urethritis due to the association of this agent with persistent and recurrent urethritis. Persistent urethritis after doxycycline treatment may be caused by doxycycline resistant $U$. urealyticum. A single dose of $1 \mathrm{~g}$ oral azithromycin should be administered, and if the infection is associated with $T$. vaginalis, single oral dose of $2 \mathrm{~g}$ metronidazole should be added (49).

\section{Chlamydia trachomatis}

First-line treatment of uncomplicated urogenital chlamydial infections should be a single dose of 1 $\mathrm{g}$ azithromycin. Azithromycin is still an option in 
pregnancy and in women who are breastfeeding. Doxycycline, $100 \mathrm{mg}$ two times daily for 7 days, is a suitable alternative (50). Another alternative treatment is josamycin, $500-1000 \mathrm{mg}$ two times daily for 7 days. Josamycin is used with success in some countries (51).

Earlier trials indicate that the first-line treatment is more than $95 \%$ effective. However, recent evidence suggests that treatment failure may occur in more than $5 \%$ of patients. Studies in women, not at risk of reinfection, showed treatment failure rates of approximately $8 \%$, while in men treated with a single dose azitrhromycin it was $23 \%$ (52).

An American study showed a higher cure rate when using doxycycline than azithromycin. Cure rate in patients treated with doxycycline $(100 \mathrm{mg}$ twice daily for 7 days) was $94.8 \%$, while in patients treated with azithromycin (single dose of $1 \mathrm{~g}$ ) it was $77.4 \%$. Reasons for lower cure rates may be high incidence of C. trachomatis infection and lower observed efficacy of azithromycin therapy in this study, as well as potential reinfections in high-risk population (36).

Resistance, although infrequently reported to date, may occur in C. trachomatis and is associated with treatment failure. The incidence of resistance is unknown, but it is estimated to be very low (53). In experiments with multiple cultivation passages, resistant mutants of $C$. trachomatis to sparfloxacin, ofloxacin, ciprofloxacin, rifampin and azithromycin were found. In one in vitro experiment, doxycycline showed the least activity against C. trachomatis compared with azithromycin or fluoroquinolones. Ofloxacin activity was found to be almost similar to azithromycin (54). Thus, therapy of $\mathrm{C}$. trachomatis is initiated empirically.

\section{Conclusion}

Antimicrobial therapy and prevention are essential elements in the management of bacterial urethritis. The increase in bacterial resistance to existing antimicrobial agents indicates that timely revision of treatment guidelines is necessary, as well as development of new antimicrobial compounds and vaccines that are a real challenge for researchers due to the antigenic variations of bacteria.

\section{References}

1. Centers for Disease Control and Prevention. Sexually transmitted diseases surveillance c 2008 [updated 2009 Nov 16; cited 2012 Nov 25]. Available from: http:/www.cdc.gov/ std/stats08/tables/2.htm

2. Miller WC, Ford CA, Morris M, Handcock MS, Schmitz JL, Hobbs MM, et al. Prevalance of chlamydial and gonococcal infections among young adults in the United States. JAMA 2004;291(18):2229-36.

3. Shahmanesh M, Moi H, Lassau F, Janier M. European guideline on the management of male non-gonococcal urethritis. Int J STD AIDS 2009;20:458-64.

4. Bradshaw CS, Tabrizi SN, Fairley CK, Morton AN, Rudland E, Garland SM. The association of Atopobium vaginae and Gardnerella vaginalis with bacterial vaginosis and recurrence after oral metronidazole therapy. J Infect Dis 2006;194(6):82836.

5. Morton RS. Gonorrhea: biological features of Neisseria gonorrhoeae. London: W.B. Saunders; 1977. p. 12-60.

6. Mahoney JF, Ferguson C, Buchholtz M, von Slyke CJ. The use of penicillin sodium in the treatment of sulfonamide-resistant gonorrhea in men: a preliminary report. Am J Syph Gonor Vener Dis 1943;27:525-8.

7. Willcox RR. A survey of problems in the antibiotic treatment of gonorrhoea: with special reference to South-East Asia. Br J Vener Dis 1970;46:217-42.

8. Philips I. Beta-lactamase producing, penicillin-resistant gonococcus. Lancet 1976;2:656-7.

9. Schwarcz SK, Zenilman JM, Schnell D, Knapp JS, Hook EW 3rd, Thompson S, et al. National surveillance of antimicrobial resistance in Neisseria gonorrhoeae: the gonococcal isolate surveillance project. JAMA 1990;264:1413-7.

10.Tapsall JW, Ndowa F, Lewis DA, Unemo M. Meeting the public health challenge of multidrug and extensively drug resistant Neisseria gonorrhoeae. Expert Rev Anti Infect Ther 2009;7:821-34.

11.Tapsall JW. Antibiotic resistance in Neisseria gonorrhoeae. Clin Infect Dis 2005; 41 (Suppl 4):S263-8.

12.Centers for Disease Control and Prevention (CDC). Update to CDC's sexually transmitted diseases treatment guidelines, 2006: fluoroquinolones no longer recommended for treatment of gonococcal infections. MMWR Morb Mortal Wkly Rep 2007;56:332-6.

13. Bignell C, Garley J. Azithromycin in the treatment of infection with Neisseria gonorrhoeae. Sex Transm Infect 2010;86:422-6.

14. Chisholm SA, Neal TJ, Alawattegama AB. Emergence of high-level azithromycin resistance in Neisseria gonorrhoea in England and Wales. J Antimicrob Chemother 2009;64:353-8.

15.Moran JS, Levine WC. Drugs of choice for the treatment of uncomplicated gonococcal infections. Clin Infect Dis 1995;20(Suppl 1):S47-65.

16.Newman LM, Moran JS, Workowski KA. Update on the management of gonorrhea in adults in the United States. Clin Infect Dis 2007;44(Suppl 3):S84-101.

17.Akasaka S, Muratani T, Yamada Y, Inatomi H, Takahachi K, 
Matsumoto T. Emergence of cephem- and aztreonam-highresistant Neisseria gonorrhoeae that does not produce betalactamase. J Infect Chemother 2001;7(1):49-50.

18. Unemo M, Golparian D, Syversen G, Vestrheim DF, Moi $\mathrm{H}$. Two cases of verified clinical failures using internationally recommended first-line cefixime for gonorrhoea treatment, Norway, 2010. Euro Surveill 2010;15(47).

19.Ohnishi M, Golparian D, Shimuta K, Saika T, Hoshina S, Iwasaku $\mathrm{K}$, et al. Is Neisseria gonorrhoeae initiating a future era of untreatable gonorrhea?: detailed characterization of the first strain with high-level resistance to ceftriaxone. Antimicrob Agents Chemother 2011;55(7):3538-45.

20.Unemo M, Golparian D, Nicholas R, Ohnishi M, Gallay A, Sednaoui P. High-level cefixime- and ceftriaxone-resistant Neisseria gonorrhoeae in France: novel penA mosaic allele in a successful international clone causes treatment failure. Antimicrob Agents Chemother 2012;56(3):1273-80.

21.Lewis DA. The Gonococcus fights back: is this time a knock out? Sex Transm Infect 2010;86:415-21.

22.Bignell C, Fitzgerald M. UK national guideline for the management of gonorrhoea in adults, 2011. Int J STD AIDS 2011;22:541-7.

23.Ison CA. Antimicrobial resistance in sexually transmitted infections in the developed world: implications for rational treatment. Curr Opin Infect Dis 2012;25:73-8.

24.Bignell C, Unemo M. 2012 European guideline on the diagnosis and treatment of gonorrhoea in adults, IUSTI 2012. [cited 2012 Nov 25]. Available from: http://www.iusti.org/ regions/Europe/pdf/2012/Gonorrhoea_2012.pdf.

25.PHAC. Important notice. Public health information update on the treatment for gonococcal infection. 21 December 2011. [cited 2012 Nov 25]. Available from: http://www.phac-aspc. gc.ca/std-mts/sti-its/alert/2011/alert-gono-eng.php

26. Ross JD, Lewis DA. Cephalosporin resistant Neisseria gonorrhoeae: time to consider gentamicin? Sex Transm Infect 2012; 88(1):6-8.

27.Golparian D, Fernandes P, Ohnishi M, Jensen JS, Unemo $M$. In vitro activity of the new fluoroketolide solithromycin (CEM-101) against a large collection of clinical Neisseria gonorrhoeae isolates and international reference strains, including those with various high-level antimicrobial resistance: potential treatment option for gonorrhea? Antimicrob Agents Chemother 2012;56(5):2739-42.

28.Still JG, Schranz J, Degenhardt TP, Scott D, Fernandes P, Gutierrez MJ, et al. Pharmacokinetics of solithromycin (CEM-101) after single or multiple oral doses and effects of food on single-dose bioavailability in healthy adult subjects. Antimicrob Agents Chemother 2011;55(5):1997-2003.

29. Unemo M, Golparian D, Limnios A, Whiley D, Ohnishi M, Lahra MM, et al. In vitro activity of ertapenem versus ceftriaxone against Neisseria gonorrhoeae isolates with highly diverse ceftriaxone MIC values and effects of ceftriaxone resistance determinants: ertapenem for treatment of gonorrhea? Antimicrob Agents Chemother 2012;56(7):3603-9.

30.Andersen B, Sokolowski I, Ostergaard L, Moller JK, Olesen F, Jensen JS. Mycoplasma genitalium: prevalence and behavioural risk factors in the general population. Sex Transm Infect 2007;83:237-41.

31.Totten PA, Schwartz MA, Sjostrom KE, Kenny GE, Handsfield
$\mathrm{HH}$, Weiss JB, et al. Association of Mycoplasma genitalium with nongonococcal urethritis in heterosexual men. J Infect Dis 2001;183:269-76.

32.Cazanave C, Manhart LE, Bebear C. Mycoplasma genitalium, an emerging sexually transmitted pathogen. Med Mal Infect 2012;42:381-92.

33.Humasuna R, Osada Y, Jensen JS. Antibiotic susceptibility testing of Mycoplasma genitalium by TaqMan 5'nuclease realtime PCR. Antimicrob Agents Chemother 2005;49:4993-8.

34.Shimada Y, Deguchi T, Nakane K, Yasuda M, Yokai S, Ito S, et al. Macrolide resistance-associated 23S rRNA mutation in Mycoplasma genitalium, Japan. Emerg Infect Dis 2011;17(6):1148-50.

35. Bjornelius E, Anagrius C, Bojs G, Carlberg H, Johannisson G, Johansson E, et al. Antibiotic treatment of symptomatic Mycoplasma genitalium infection in Scandinavia: a controlled clinical trial. Sex Transm Infect 2008;84(1):72-6.

36. Schwebke JR, Rompalo A, Taylor S, Sena AC, Martin DH, Lopez LM, et al. Re-evaluating the treatment of nongonococcal urethritis: emphasizing emerging pathogens: a randomized clinical trial. Clin Infect Dis 2011;52(2):163-70.

37. Wikstrom A, Jensen JS. Mycoplasma genitalium: a common cause of persistent urethritis among men treated with doxycycline. Sex Trasm Infect 2006;82(4):276-9.

38.Ray WA, Murray KT, Hall K, Arbogast PG, Stein CM. Azithromycin and the risk of cardiovascular death. N Engl J Med 2012;366:1881-90.

39.Jernberg E, Moghaddam A, Moi H. Azithromycin and moxifloxacin for microbiological cure of Mycoplasma genitalium infection: an open study. Int J STD AIDS 2008;19(10):676-9.

40.Manhart LE, Broad JM, Golden MR. Mycoplasma genitalium: should we treat and how? Clin Infect Dis 2011;53(Suppl 3):S129-42.

41.Horner P, Thomas B, Gilroy CB, Egger M, Taylor-Robinson D. Role of Mycoplasma genitalium and Ureaplasma urealyticum in acute and chronic nongonococcal urethritis. Clin Infect Dis 2001;32:995-1003.

42.Kenny GE. Genital mycoplasmas: Mycoplasma genitalium, Mycoplasma hominis et Ureaplasma species. In: Mandel GL, Bennett JE, Dolin R. Principles and practice of infectious diseases. Vol 2. Philadelphia, Pa: Elsevier Churchill Livingstone; 2005. p. 2280-3.

43.Uuskula A. Kohl PK. Genital micoplasmas, including Mycoplasma genitalium, as sexually transmitted agents. Int J STD AIDS 2002;13:79-85.

44.Taylor-Robinson D, Furr PM, Webster AD. Ureaplasma urealyticum causing persistent urethritis in a patient with hypogammaglobulinaemia. Genitourin Med 1985;61:404-8.

45.Palu G, Valisena S, Barile MF, Meloni GA. Mechanisms of macrolide resistance in Ureaplasma urealyticum: a study on collection and clinical strains. Eur J Epidemiol 1989;5:146-53.

46.Pereyre S, Metifiot M, Cazanave C, Renaudin H, Charron A, Bebear $\mathrm{C}$, et al. Characterisation of in vitro-selected mutants of Ureaplasma parvum resistant to macrolides and related antibiotics. Int J Antimicorb Agents 2007;29:207-11.

47. Waites KB, Bebear CM, Roberston JA, Talkington DF, Kenny GE. Cumitech 34: laboratory diagnosis of mycoplasmal infections. Washington DC: American Society for 
Microbiology; 2001.

48.Lu C, Ye TL, Zhu GX, Feng PY, Ma H, Lu RB, et al. Phenotypic and genetic characteristics of macrolide and lincosamide-resistant Ureaplasma urealyticum isolated in Guangzhou, China. Curr Microbiol 2010;61:44-9.

49. Centers for Disease Control and Prevention: Sexually transmitted diseases treatment guidelines. MMWR 2010:42 [cited 2012 Nov 25]. Available from: http://www.cdc.gov/ $\mathrm{mmwr} / \mathrm{pdf} / \mathrm{rr} / \mathrm{rr} 5912$.pdf.

50. Horner P, Boag F. UK national guideline for the management of genital tract infection with Chlamydia trachomatis. London: BASHH, 2006. [cited 2012 Nov 25]. Available from: hpp:// www.bashh.org/documents/61/61.pdf.

51.Lanjouw, Ossewaarde JM, Stary A, Boag F. European guideline for the management of Chlamydia trachomatis infections,
IUSTI 2010. [cited 2012 Nov 25]. Available from: http:// www.iusti.org/regions/Europe/pdf/2010/Euro_Guideline_ Chlamydia_2010.pdf.

52.Horner PJ. Azithromycin antimicrobial resistance and genital Chlamidya trachomatis infection: duration of therapy may the key to improving efficacy. Sex Transm Infect 2012;88:154-6.

53. Wang SA, Papp JR, Stamm WE, Peeling RW, Martin DH, Holmes KK. Evaluation of antimicrobial resistance and treatment failures for Chlamydia trachomatis: a meeting report. J Infect Dis 2005;191:917-23.

54.Smelov V, Perekalina T, Gorelov A, Smelova N, Artemenko N, Norman L. In vitro activity of fluoroquinolones, azithromycin and doxocycline against Chlamydia trachomatis cultured from men with chronic lower urinary tract symptoms. Eur Urol 2004;46(5):647-50.

\section{Uretritis i antimikrobna rezistencija}

\section{Sažetak}

Uvod. Uretritis je klinički sindrom za koji je karakteristična pojava mukopurulentnog ili purulentnog uretralnog sekreta, sa dizurijom ili bez nje, zbog povećanog broja polimorfonuklearnih leukocita u prednjoj uretri. Antimikrobna terapija i mere prevencije su osnova u borbi protiv bakterijskih uretritisa. Ovu borbu remeti antimikrobna rezistencija te je i terapija neuspešna, a postoji i mogućnost komplikacija uretritisa.

Neisseria gonorrhoeae. Tokom proteklih decenija mnogi antibiotici kojima su lečeni pacijenti oboleli od gonoreje, kao što su penicillin, tetraciklini, hinoloni i makrolidi, više nisu lekovi izbora. Danas su terapija izbora cefalosporini treće generacije. Prvi podaci o rezistenciji na cefalosporine objavljeni su u Japanu 2000. godine, što ukazuje na to da bi lečenje ove infekcije moglo da predstavlja veliki problem u budućnosti.

Mycoplasma i ureaplasma. U terapiji se primenjuju azitromicin i doksiciklin. Istraživanja pokazuju da je azitromicin superiorniji od doksiciklina, ali sa rizikom od razvoja azitromicin-indikovane rezistencije. Zbog toga danas nema opšteprihvaćene standardne terapije. Chlamydia trachomatis. Prva linija terapije je primena azitromicina. Istraživanja pokazuju da je neuspeh terapije veći od ranije objavljenih $5 \%$ lečenih.

\section{Ključne reči}

Uretritis + etiologija + terapija + klasifikacija + prevencija i kontrola; Antimikrobna rezistencija 